\title{
Analisis Kemampuan Peserta Didik dalam Memecahkan Masalah Konsep Gerak Berbentuk Grafik dengan Tes Diagnostik pada Siswa SMP
}

\author{
Wayan Murtayasa $^{1}{ }^{*}$, La Sahara $^{2)}$, Rosliana Eso ${ }^{3)}$ \\ 1)*Mahasiswa Jurusan Pendidikan Fisika, Universitas Halu Oleo, Indonesia \\ ${ }^{2), 3)}$ Dosen Jurusan Pendidikan Fisika, Universitas Halu Oleo, Indonesia \\ *Korespondensi Email: wayanmurtayasa@gmail.com
}

\begin{abstract}
Abstrak: Penelitian ini bertujuan untuk mendeskripsikan kemampuan dan profil kesulitan peserta didik dalam memecahkan masalah konsep gerak yang berbentuk grafik dengan menggunakan tes diagnostik pada peserta didik kelas VIII SMP Negeri 10 Kendari. Metode yang digunakan dalam penelitian ini adalah metode Deskriptif. Subjek dalam penelitian ini adalah 30 peserta didik kelas $\mathrm{VIII}_{3}$ SMP Negeri 10 Kendari tahun ajaran 2018/2019 dan dilakukan pada bulan Mei 2019. Teknik pengumpulan data dalam penelitian ini dilakukan dengan pemberian instrumen penelitian berbentuk tes uraian. Teknik analisis data berupa analisis hasil tes kemampuan dan kesulitan terkait pemecahan masalah berbentuk grafik. Hasil penelitian ini menunjukkan bahwa rata-rata kemampuan peserta didik dalam memecahkanan masalah konsep gerak berbentuk grafik adalah kategori kurang dengan masing-masing kemampuan interpretasi sebesar 10,14\%, interpolasi sebesar 30\%, ekstrakpolasi sebesar 16,66\% dan kemampuan transformasi sebesar 19,11\%. Untuk profil kesulitan peserta didik berdasarkan pencapaian KKM , peserta didik masih mengalami kesulitan untuk semua indikator dengan rata-rata kategori adalah kategori lemah. Sedangkan profil kesulitan berdasarkan profil materi, peserta didik masih mengalami kesulitan untuk semua sub materi dengan rata-rata kategori lemah.
\end{abstract}

Kata Kunci: Kemampuan pemecahan masalah; Pemahaman grafik; Tes diagnosis; Pembelajaran Fisika

Abstract: In this study aims to describe the ability and difficulty profile of students in solving graphic motion concept problems using diagnostic tests on grade VIII students of SMP Negeri 10 Kendari. The method used in this research is descriptive method. The subjects in this study were 30 students of class $\mathrm{VIII}_{3}$ of Junior High School 10 Kendari in the 2018/2019 school year and conducted in May 2019. Data collection techniques in this study were carried out by providing research instruments in the form of description tests. Data analysis techniques in the form of analysis of the results of tests of ability and difficulty associated with solving graphical problems. The results of this study indicate that the average ability of students in solving graphic motion concepts is less category with each interpretation ability of $10.14 \%$, interpolation of $30 \%$, extractpolation of $16.66 \%$ and transformation ability of $19,11 \%$. To profile the difficulties of students based on the KKM achievement, students still experience difficulties for all indicators with the average category being the weak category. While the difficulty profile is based on the material profile, students still experience difficulties for all sub materials with an average weak category.

Keywords: Problem Solving Ability; Undestanding graphs; Diagnostic tests; Physics learning

\section{PENDAHULUAN}

Pendidikan adalah bagian yang sangat penting dalam kehidupan manusia, sebab dengan pendidikan inilah manusia dapat mengarungi kehidupan sesuai fungsinya (Hunaidah, dkk. 2018). Menurut UU No. 20 Tahun 2003, pendidikan adalah usaha sadar dan terencana untuk mewujudkan suasana belajar dan proses pembelajaran agar peserta didik secara aktif mengembangkan potensi dirinya untuk memiliki kekuatan spiritual keagamaan, pengendalian diri, kepribadian, kecerdasan, akhlak mulia, serta keterampilan yang diperlukan dirinya, masyarakat, bangsa dan negara.

Pada proses pembelajaran yang dilakukan, ada hambatan yang dialami oleh guru dan peserta didik. Salah satu diantaranya adalah kendala yang dihadapi oleh peserta didik, yaitu mereka cenderung sulit untuk memecahkan masalah khususnya pada pelajaran fisika (Erniwati, dkk. 2020). Para pendidik dihadapkan dengan sejumlah karakteristik yang 
beraneka ragam. Ada yang dapat menempuh kegiatan belajarnya secara lancar dan berhasil tanpa mengalami kesulitan, namun disisi lain tidak sedikit pula peserta didik yang justru dalam belajarnya mengalami berbagai kesulitan. Seperti yang diungkapkan oleh Setiandari (2013) bahwa peserta didik mengalami kesulitan dalam memahami konsep, menerapkan konsep, menggunakan simbol fisika, hitungan, membaca grafik dan memahami soal.

Pelajaran fisika merupakan salah satu pelajaran yang dianggap sulit dipahami dan menakutkan bagi sebagian besar peserta didik sekolah menengah jika hanya mengutamakan pemahaman sendiri (Kawuri, dkk. 2019). Sebab mempelajari fisika itu tidaklah mudah, harus melalui tahapan-tahapan yang berurutan berdasarkan latihan-latihan serta pengalaman belajar sebelumnya, dalam hal ini konsep-konsep dasar harus dilibatkan dalam menyelesaikan masalah fisika yang kompleks. Hal ini berarti proses berpikir peserta didik harus dapat di padukan kedalam pembelajaran dari hal-hal abstrak kapada hal-hal yang konkrit sehingga dalam proses belajar mengajar fisika, peserta didik harus terus menerus menemukan dan mengembangkan konsep secara teratur dan berencana sehingga dapat memahami konsep-konsep fisika dengan baik untuk mengubah anggapan bahwa pelajaran fisika itu sulit dipahami.

Mengingat begitu pentingnya peranan ilmu fisika, sudah semestinya fisika dipahami dengan baik oleh peserta didik. Fisika sebagai sebuah ilmu pengetahuan yang dekat dengan fenomena alam, dapat diterjemahkan dalam berbagai bentuk representasi. Salah satunya yaitu representasi dalam bentuk grafik. Representasi merupakan bentuk yang dapat menggambarkan, mewakili atau melambangkan sesuatu obyek. Hasil penelitian Bunawan, dkk (2015), menunjukkan bahwa pembacaan grafik dan keterampilan menginterpretasi grafik pada peserta didik masih belum memadai yang dalam menganalisis grafik bergantung pada jenis grafik dan level atau tipe pertanyaan.

Penelitian mengenai interpretasi grafik yang dilakukan oleh Yustiandi \& Saepuzaman (2017), diperoleh bahwa peserta didik banyak mengalami kesulitan salah satunya dalam penentuan kecepatan sesaat yang dimiliki benda dalam grafik posisi sebagai fungsi waktu. Begitu pula dengan penelitian yang dilakukan oleh Setyono, dkk. (2016), menunjukan bahwa rata-rata kemampuan pemecahan masalah grafik masih rendah dimulai dari kemampuan interpretasi grafik Pada pokok bahasan gerak, grafik dijadikan sebagai salah satu representasi untuk menjelaskan konsep gerak. Konsep-konsep gerak meliputi perpindahan, kecepatan dan percepatan yang berhubungan dengan fungsi waktu. Bentuk-bentuk gerakan partikel (benda) dapat diketahui dengan menelaah grafik gerak. Materi ini menjadi dasar untuk mempelajari materi-materi berikutnya. Oleh sebab itu, penanaman konsep tentang grafik kinematika merupakan hal penting untuk dipahami. Untuk memahami konsep tersebut, maka peserta didik dituntut untuk melatih kemampuan interpretasi (menafsirkan) khususnya pada grafik kinematika. Hasil penelitian yang dilakukan Mustain (2015) menggunakan pengujian tes diagnostik Test of Graphing in Science (TOGS) menunjukkan bahwa peserta didik tidak dapat membaca grafik dengan baik, sedangkan dengan Web Inquiry Science Environment (WISE) ditemukan bahwa peserta didik memiliki kesulitan dalam menginterpretasi grafik dan data.

Berdasarkan keterangan dari guru fisika SMPN 10 Kendari, pembelajaran fisika khususnya materi gerak lurus masih dirasakan sulit oleh peserta didik, belum mampu menggambarkan atau membaca grafik gerak lurus secara tepat. Peserta didik tidak mampu mengidentifikasi jenis-jenis grafik gerak lurus. Hal ini mengindikasikan kemampuan peserta didik menafsirkan grafik masih tergolong rendah. Bentuk kesalahan dalam menafsirkan grafik ialah mereka menyamakan grafik posisi, kecepatan, dan percepatan terhadap waktu. Kesalahan tersebut disebabkan kurangnya konsepsi tentang grafik. Oleh karena itu, peserta didik memerlukan bantuan secara cepat dan tepat, agar permasalahan yang mereka hadapi dapat diatasi secara komprehensif. Masalah kesulitan belajar peserta didik dapat ditemukan dengan memberikan tes diagnostik. Tes diagnostik perlu dilakukan untuk mengetahui kelemahan dan kekuatan peserta didik terhadap penguasaan suatu bagian atau keseluruhan materi pelajaran.

Berdasarkan uraian tersebut peneliti tertarik untuk melakukan penelitian tentang kemampuan pemecahan masalah fisika dengan judul analisis kemampuan peserta didik dalam memecahkan masalah konsep gerak berbentuk grafik dengan tes diagnostik pada kelas VIII SMP Negeri 10 Kendari. Permasalahan yang akan dikaji pada penelitian ini adalah: (1). Bagaimanakah kemampuan peserta didik dalam memecahkan masalah konsep gerak yang berbentuk grafik dengan menggunakan tes diagnostik pada peserta didik kelas VIII SMP 
Negeri 10 Kendari?; (2). Bagaimanakah profil kesulitan peserta didik dalam memecahkan masalah konsep gerak yang berbentuk grafik berdasarkan pencapaian KKM dengan menggunakan tes diagnostik pada peserta didik kelas VIII SMP Negeri 10 Kendari? (3). Bagaimanakah profil kesulitan peserta didik dalam memecahkan masalah konsep gerak yang berbentuk grafik terhadap profil materi dengan menggunakan tes diagnostik pada peserta didik kelas VIII SMP Negeri 10 Kendari?. Tujuan yang diharapkan pada studi ini adalah tersedianya sumber referensi dan rujukan mengenaik kemampuan peserta didik dalam memecahkan masalah konsep gerak yang berbentuk grafik dengan menggunakan tes diagnostik pada peserta didik kelas VIII SMP Negeri 10 Kendari.

\section{METODE}

Jenis penelitian yang digunakan dalam penelitian ini adalah penelitian deskriptif. Penelitian deskriptif memusatkan perhatian pada masalah-masalah aktual sebagaimana adanya pada saat penelitian berlangsung.

Penelitian ini dilakukan pada peserta didik kelas VIII SMP Negeri 10 Kendari semester genap tahun ajaran 2018/2019 yang terdistribusi pada 8 kelas paralel yaitu dari kelas VIII1 sampai VIII8. Berdasarkan informasi dari guru, penyebaran peserta didik di setiap kelas paralel tidak dibedakan berdasarkan tingkat kemampuannya. Oleh karena itu, untuk keperluan penelitian ini akan dipilih 1 kelas sebagai sasaran penelitian. Pemilihan kelas sebagai subjek penelitian dilakukan secara acak atau tidak didasari oleh kriteria tertentu (Sugiyono, 2017) seperti mengambil kelas yang memiliki nilai ratarata tinggi, sedang maupun rendah. Hal ini dikarenakan tingkat prestasi belajar kelas VIII di SMP Negeri 10 Kendari hampir sama. Oleh karena itu, kelas manapun yang terpilih sebagai subjek penelitian akan mendapatkan hasil yang tidak jauh berbeda dengan kelas-kelas lain yang tidak terpilih sebagai subjek penelitian. Dari cara tersebut diperoleh kelas VIII3 yang berjumalah 30 peserta didik sebagai subjek penelitian.

Data yang diperoleh dalam penelitian ini adalah data hasil tes dan wawancara. Data hasil tes berupa kemampuan pemecahan masalah konsep gerak berbentuk grafik. Sedangkan, data hasil wawancara berupa konfirmasi ulang proses pengerjaan tes tertulis untuk mengetahui lebih lanjut terkait cara atau pola berpikir subjek penelitian terhadap kemampuan pemecahan masalah konsep gerak berbentuk grafik dari tes yang diberikan, serta sejauh mana kemampuan peserta didik dalam menyelesaikan soal-soal yang diberikan guru selama pembelajaran di kelas terkait materi gerak lurus.

Metode pengumpulan data menggunakan tes, wawancara. Sedangkan teknik analisis data terdiri dari analisis kemampuan pemecahan masalah, analisis kesulitan belajar peseta didik. Analisis profil kesulitan peserta didik dan pemecahan masalah dianalisis menggunakan persentase skor peserta didik digunakanpersamaan (1) Setyono, dkk. 2016:

$$
\% \text { skor }=\frac{\text { skor siswa yang mengalami kesulit an }}{\text { skor siswa maksimum }} \times 100 \%
$$

Dengan ketentuan:

KKM ketuntasan: $65 \%$, peserta didik mengalami kesulitan jika :

$\%$ skor $\leq 35 \%$

$\%$ skor $>35 \%$
: kategori kuat

: kategori lemah
Menurut Setyono, dkk. ( 2016) ketentuan kategori kesulitan peserta didik dan pemecahan masalah dapat dilihat pada Tabel 1.

Tabel 1. Kriteria kesulitan peserta didik

\begin{tabular}{cc}
\hline Persentase $(\%)$ & Kategori \\
\hline $80-100$ & Sangat Tinggi \\
$66-79$ & Tinggi \\
$40-65$ & Sedang \\
$0-39$ & Rendah \\
\hline
\end{tabular}

Untuk mendukung hasil analisis tentang profil kesulitan pemecahan masalah peserta didik di atas maka ditambah dengan hasil wawancara yang telah dilakukan untuk mendeskripsikan kesulitan peserta didik dalam pemecahan masalah konsep gerak yang berbentuk grafik 
HASIL PENELITIAN

1. Kemampuan Masalah Konsep Gerak Berbentuk Grafik

Kemampuan memecahkan masalah konsep gerak berbentuk grafik yang diukur yaitu kemampuan pemecahan masalah yang berkaitan dengan kemampuan interpretasi grafik, kemampuan memprediksi grafik, baik interpolasi maupun ekstrapolasi dan kemampuan transformasi suatu grafik (Setyono, 2016). Proses pengambilan data dilakukan dengan menggunakan tes diagnostik untuk mengukur kemampuan peserta didik dalam menyelesaikan masalah konsep gerak berbentuk grafik. Hasil pengambilan data digambarkan pada Gambar 1.

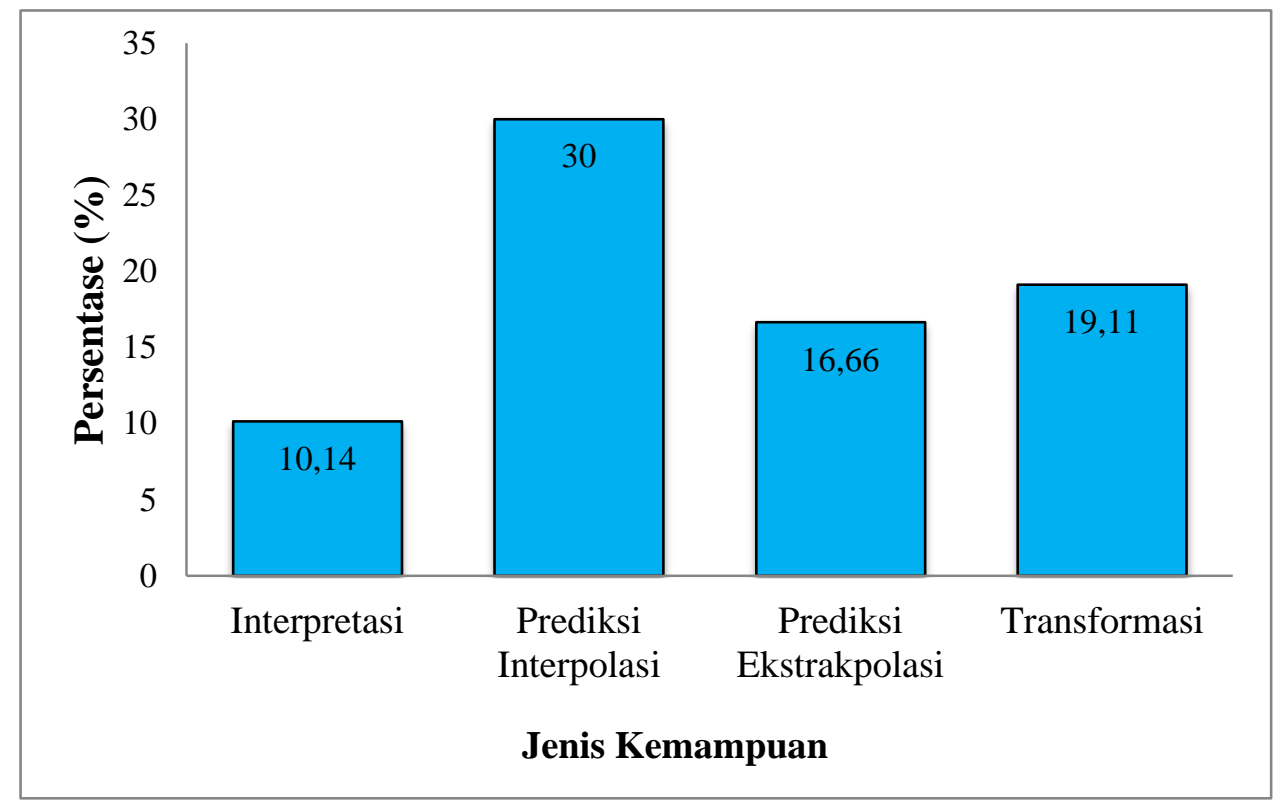

Gambar 1. Kemampuan pemecahan masalah berbentuk grafik

Gambar 1 Menunjukan bahwa kemampuan peserta didik dalam pemecahan masalah berbentuk grafik yang paling tinggi adalah kemampuan peserta didik dalam menginterpolasi grafik, yaitu sebesar $30 \%$. Sedangkan persentase yang paling rendah adalah kemampuan peserta didik dalam menginterpretasi grafik, yaitu sebesar 10,14\%.

\section{Profil Kesulitan Peserta Didik Berdasarkan Pencapaiakn KKM (Kritetia Ketuntasan Minimum)}

Hasil penelitian profil kesulitan peserta didik berdasarkan pencapaian KKM digambarkan oleh Gambar

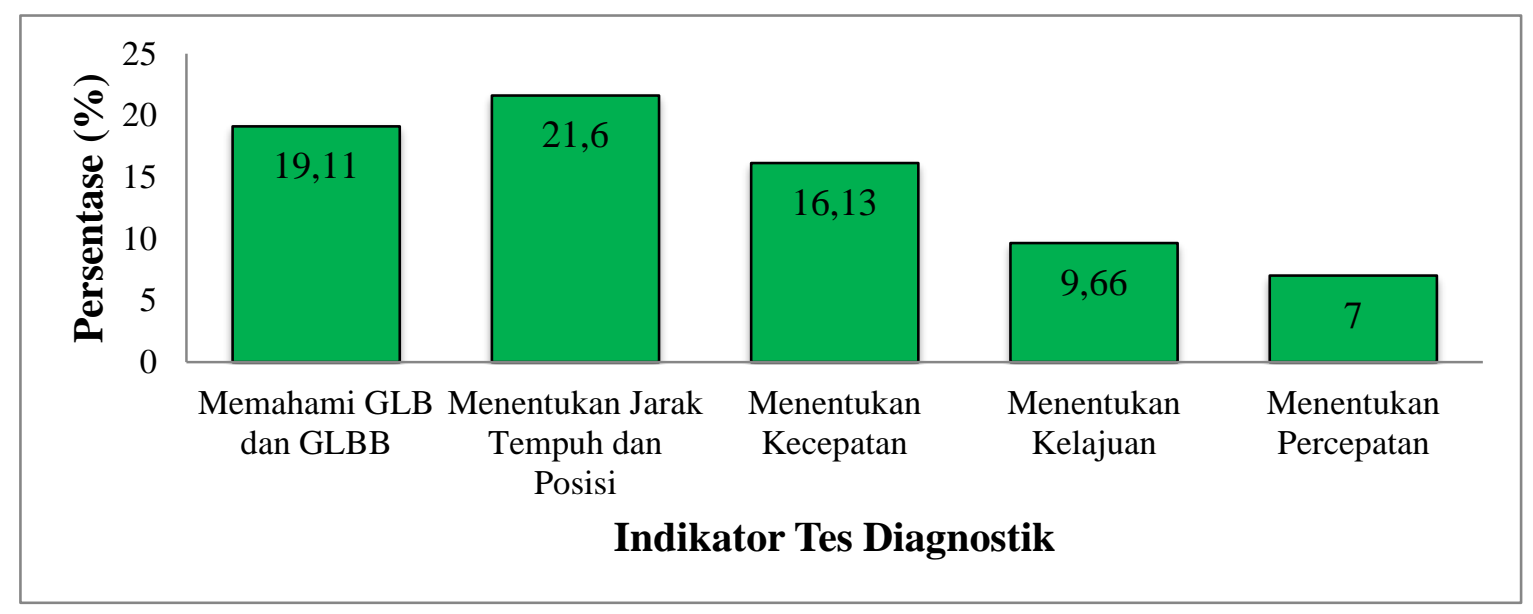


Gambar 2. Profil kesulitan berdasarkan pencapaian KKM

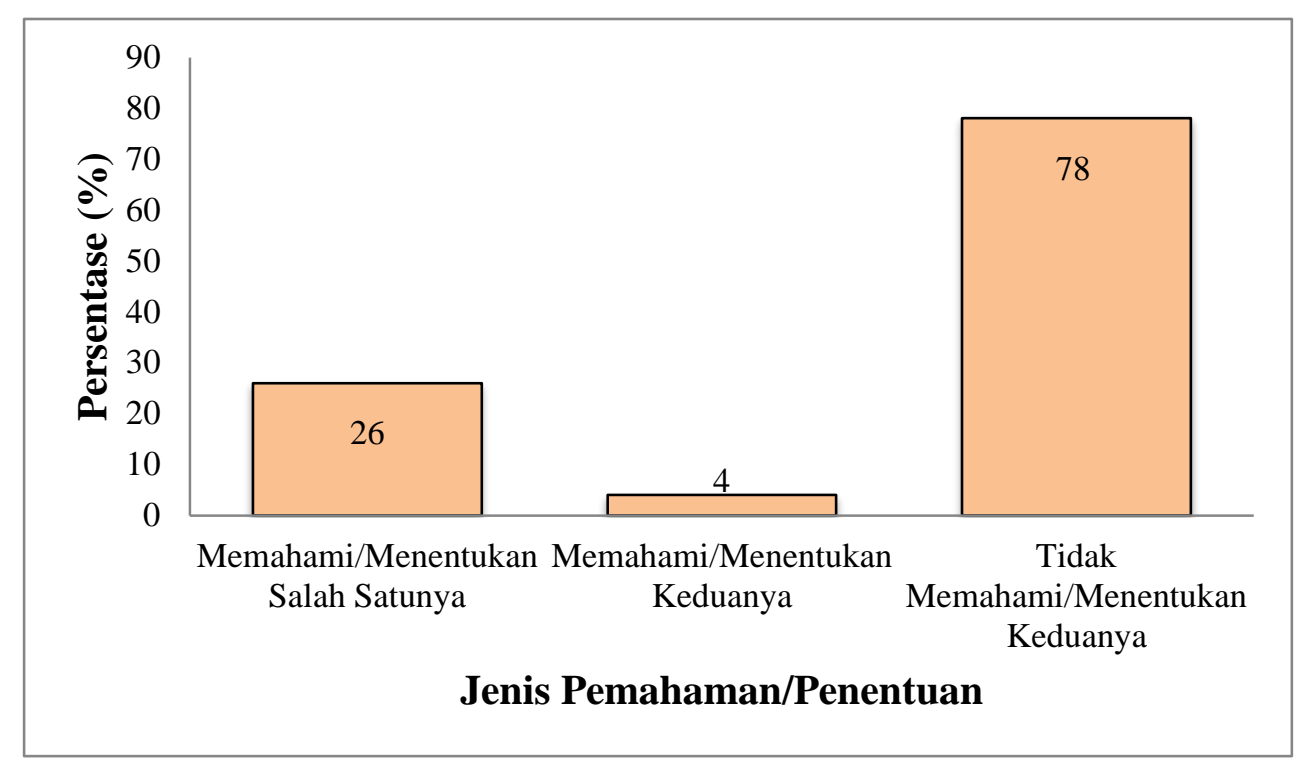

Gambar 3. Profil kesulitan pemahaman/penentuan 5 indikator berdasarkan pencapaian KKM

Berdasarkan Gambar 3 Menunjukan bahwa kesulitan peserta didik berdasarkan pencapaian KKM memiliki persentase kesulitan paling tinggi adalah indikator menentukan jarak tempuh dan posisi, yaitu sebesar $21,6 \%$. Sedangkan persentase kesulitan yang paling rendah adalah indikator menentukan percepatan, yaitu sebesar $7 \%$. Gambar 3 menunjukkan bahwa persentase pemahaman/penentuan 5 indikator berdasarkan pencapaian KKM menyatakan bahwa hanya 4\% saja yang dapat memaham/menentukan keduanya, 26\% dapat menentukan salah satunya dan $78 \%$ tidak dapat memahami/menentukan keduanya.

\section{Profil Kesulitan Peserta Didik terhadap Materi}

Analisis kesulitan peserta didik terhadap profil materi bertujuan untuk mengetahui sub - sub materi yang sudah dan belum dikuasai oleh peserta didik yang sub materi dari penelitian ini yaitu jarak dan perpindahan; kecepatan dan kelajuan; percepatan; gerak lurus beraturan (GLB); serta gerak lurus berubah beraturan (GLBB) Berikut ini profil kesulitan peserta didik terhadap profil materi yang diperlihatkan pada Gambar 4.

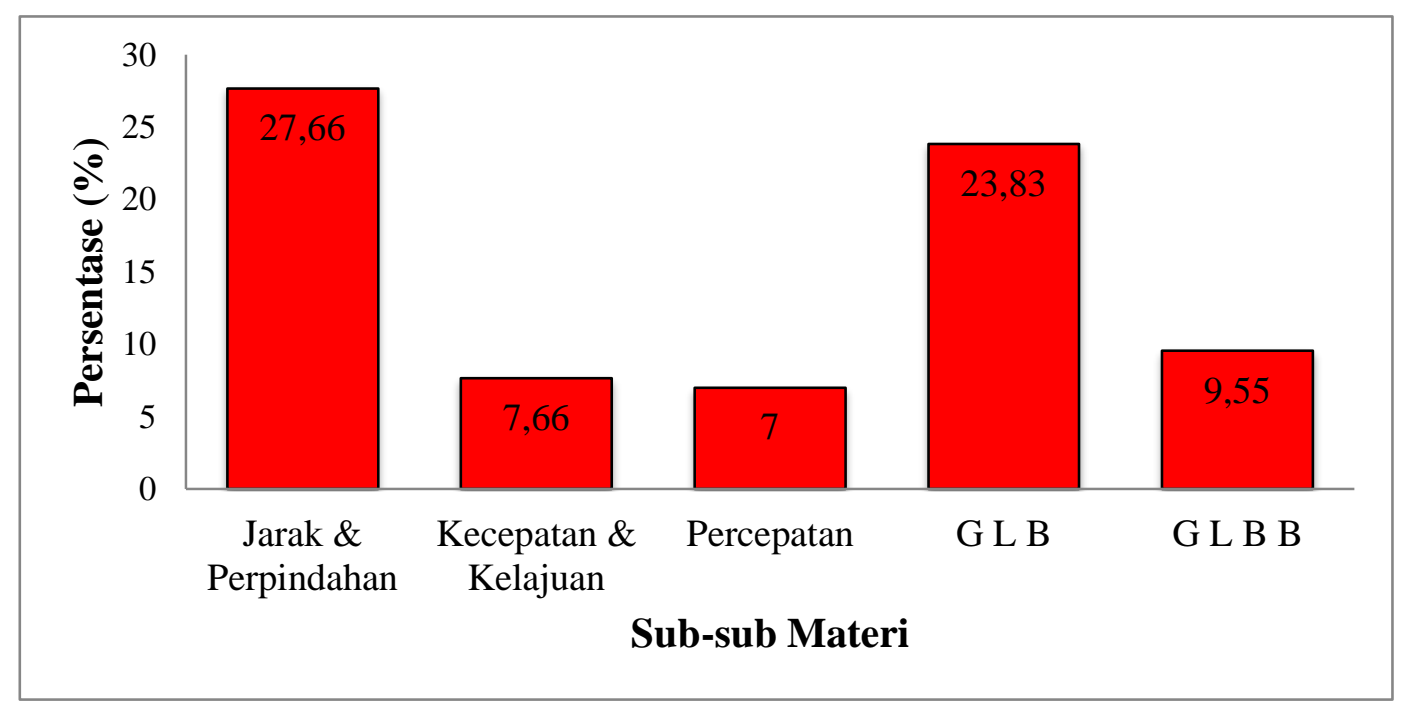

Gambar 4. Profil kesulitan peserta didik terhadap profil materi 
Dari Gambar 4 dapat diketahui bahwa peserta didik mengalami kesulitan paling besar terletak pada sub materi jarak dan perpindahan dengan persentase sebesar 27,66 \% dan sub materi gerak lurus beraturan dengan persentase sebesar $23,83 \%$. Sedangkan peserta didik mengalami kesulitan paling rendah terdapat pada sub materi kecepatan dan kelajuan dengan persentase sebesar 7,66 \% dan sub materi percepatan dengan pesrsentase sebesar 7 $\%$.

\section{PEMBAHASAN}

Hasil penelitian dari kemampuan ini yang disajikan pada Gambar 1 menunjukan bahwa kemampuan peserta didik pada kemampuan ini tergolong kurang sesuai kriteria yang ditunjukkan oleh Tabel 1. Kemampuan interpretasi grafik disini mencakup beberapa indikator, yaitu menghitung gradien dan mengetahui besaran apa yang ditunjukan gradien, serta dapat mengambil informasi dari grafik tersebut. Sebagian peserta didik dapat menghitung gradien yang ditunjukan grafik, tetapi tidak dapat mengetahui besaran apa yang dimaksud seperti jawaban peserta didik untuk soal yang menguji kemampuan dalam menentukan percepatan berdasarkan grafik hubungan kecepatan terhadap waktu. Hal ini menunjukkan bahwa peserta didik tidak mengetahui satuan tepat yang menunjukkan bahwa peserta didik tersebut hanya mengetahui perhitungan matematisnya tanpa mengetahui besaran apa yang dicari.

Berdasarkan temuan ini, nampak bahwa kemampuan pemecahan masalah dalam menginterpretasi grafik hanya $10,14 \%$. Ini menunjukkan masih banyak peserta didik yang mengalami kesulitan dalam menyelesaikan masalah yang berbentuk grafik pada jenis kemampuan interpretasi grafik. Hal ini terjadi diduga karena peserta didik masih memiliki keyakinan yang kuat terhadap konsepsinya yang kurang tepat.

Pada aspek kemampuan memprediksi indikator yang diukur yaitu memperkirakan berdasarkan grafik baik itu keadaan di dalam grafik/interpolasi maupun keadaan di luar grafik/ekstrapolasi. Kemampuan memprediksi dalam penelitian ini terbatas pada bentuk grafik linier. Sesuai dengan data yang disajikan pada Gambar 1. Pada kemampuan memprediksi keadaan di dalam grafik/interpolasi dapat digolongkan kurang sesuai kriteria yang ditunjukkan oleh Tabel 1. Pada kemampuan memprediksi keadaan di luar grafik/ ekstrapolasi didapatkan persentase yang lebih buruk dari pada kemampuan interpolasi peserta didik sesuai dengan data yang disajikan pada Gambar 1 yaitu dapat digolongkan dalam kategori sangat kurang. Rata-rata kemampuan memprediksi grafik baik interpolasi maupun ekstrapolasi didapatkan persentasenya yaitu $23,33 \%$. Keterampilan memprediksi termasuk memiliki tingkat kesulitan rendah, sesuai hasil penelitian yang dilakukan Nugroho \& Darsono (2007); Albab, dkk. (2020). Pada soal yang mengukur kemampuan memprediksi, sebagian peserta didik cenderung berpikir secara kongkret dengan perkiraan seperti yang ditunjukkan pada jawaban salah satu peserta didik yang memperkirakan posisi benda pada detik ke-6 berdasarkan grafik yang tersedia. Berdasarkan wawancara dari peserta didik tersebut, dia hanya beranggapan setiap detik posisinya akan bertambah lima meter tanpa memikirkan konsep gerak lurus

Apabila ditinjau dari segi kemampuan gtrasnformasi, Kemampuan transformasi merupakan kemampuan yang tergolong memiliki kesulitan yang tinggi. Indikator dalam kemampuan tranformasi tersebut yaitu memahami makna fisis dari sebuah grafik. Memahami makna dari sebuah grafik tidaklah sederhana, karena dibutuhkan pemahaman mendalam dan kemampuan kognitif yang cukup baik agar dapat menjelaskan makna dari grafik yang ditanyakan. Pada kemampuan transformasi ini, dari hasil pengerjaan peserta didik didapatkan persentase sebesar 19,11\% sesuai yang ditunjukkan Gambar 1 . Hasil kemampuan transformasi grafik yang dimiliki peserta didik tergolong dalam kategori kurang. Hal ini sesuai dengan penelitian yang dilakukan Beichner (1994) menunjukkan bahwa kemampuan dalam mengartikan grafik masih rendah. Salah satu kesalahan yang umum peserta didik masih kesulitan dalam membedakan arti grafik jarak terhadap waktu dengan kecepatan terhadap waktu.

Kemampuan transformasi pada penelitian ini, peserta didik diminta menjelaskan dari sebuah grafik baik termasuk gerak lurus beraturan (GLB) maupun gerak lurus berubah beraturan (GLBB). Peserta didik cenderung hanya bisa menjawab bahwa grafik itu termasuk gerak GLB atau GLBB tanpa menjelaskan bagaimana kecepatan dan percepatan yang terjadi dari gerak tersebut. Secara umun untuk semua jenis kemampuan dalam memecahkan masalah konsep gerak berbentuk yg dimulai dari kemampuan interpretasi, kemampuan memprediksi dan kemampuan transformasi masih sangat rendah yang ditunjukkan dengan hasil persentase peserta didik masing-masing $10,14 \%$, 
$23,33 \%$ dan 19,11\%. Artinya bahwa kemampuan peserta didik dalam memecahkan masalah konsep gerak berbentuk dengan tes diagnostik termasuk dalam kategori kurang.

Selain itu, apabila ditinjau dari kesulitan peserta didik berdasarkan KKM menujukkan bahwa persentase peserta didik masih di bawah batas ketuntasan untuk indikator peserta didik dapat memahami grafik GLB dan GLBB. Peserta didik tidak kesulitan dalam membedakan grafik GLB dan GLBB, tetapi kesulitan dalam memahami bagaimana keadaan kecepatan dan percepatan pada grafik GLB dan GLBB. Hal ini ditunjukkan dari jawaban peserta didik untuk soal yang menuntut peserta didik mampu mengidentifikasi grafik termasuk GLB ataupun GLBB dan bagaimana kecepatan dan percepatannya, peserta didik cenderung hanya mampu menyebutkan jenis grafik tanpa menjelaskan bagaimana kecepatan dan percepatannya.

Selain pada indikator dapat memahami grafik GLB dan GLBB, peserta didik juga mengalami kesulitan pada semua indikator yang ada. Berdasarkan hasil pengerjaan peserta didik yang menunjukkan adanya kurangnya penguasaan konsep. peserta didik diminta menentukan jarak tempuh selama 4 sekon dan memprediksikan jarak pada detik ke 10 dari sebuah grafik gerak lurus beraturan dengan kecepatan $10 \mathrm{~m} / \mathrm{s}$. Dari hasil pengerjaannya, peserta didik dapat mengerjakannya untuk soal yang menentukan jarak tempuh berdasarkan grafik tetapi dapat dilihat bahwa ada kesulitan yang terjadi pada soal selanjutnya untuk menentukan kecepatan benda berdasarkan grafik gerak lurus beraturan. Berdasarkan wawancara yang dilakukan, peserta didik menjawab bahwa $S$ (jarak) dari soal yang diminta untuk dicari kecepatannya adalah 50 meter dan didapatkan dari S (jarak) pada soal sebelumnya yaitu menentukan jarak tempuh sampai detik ke 4 . Dapat disimpulkan bahwa peserta didik belum memahami konsep gerak lurus beraturan yang memiliki kecepatan yang selalu tetap

Sejalan dengan itu Pujianto dkk. (2013), melakukan penelitian tentang konsepsi peserta didik pada konsep gerak lurus beraturan menemukan bahwa sebagian besar responden memiliki konsepsi yang salah. Konsepsi yang salah ini dikarenakan peserta didik yang menjadi responden menganggap jika suatu kendaraan bergerak dengan arah dan kecepatan tetap selama 10 detik merupakan gerak lurus berubah beraturan. Berdasarkan hasil penelitian, profil kesulitan peserta didik berdasarkan pencapaian KKM untuk indikator 1 yaitu memahami grafik GLB dan GLBB diketahui bahwa dari 30 peserta didik terdapat 2 peserta didik dapat memahami keduanya, 14 peserta didik dapat memahami salah satunya dan 18 pesera didik tidak dapat memahami keduanya. Untuk indikator 2 yaitu menentukan posisi dan jarak tempuh benda diketahui bahwa 3 peserta didik dapat menentukan keduanya, 8 peserta didik dapat menentukan salah satunya dan 19 peserta didik tidak dapat menentukan keduanya. Untuk indikator 3 yaitu menentukan kecepatan sesaat dan rata-rata benda diketahui bahwa tidak ada peserta didik yang dapat menentukan keduanya, 9 peserta didik dapat menentukan salah satunya dan 21 peserta didik tidak dapat menentukan keduanya. Untuk indikator 4 yaitu menentukan kelajuan sesaat dan rata-rata diketahui bahwa 1 peserta didik saja yang dapat menentukan keduanya, tidak ada peserta didik yang dapat menentukan salah satunya dan 21 peserta didik tidak dapat menentukan keduanya. Untuk indikator 5 yaitu menentukan percepatan benda berdasarkan grafik GLB dan GLBB diketahui bahwa tidak ada peserta didik yang dapat menentukan keduanya maupun salah satunya, yang artinya 30 peserta didik tidak dapat menentukan keduanya.

Persentase untuk kelima jenis indikator menyatakan bahwa hanya $4 \%$ saja yang dapat memaham/menentukan keduanya, 26\% dapat menentukan salah satunya dan $78 \%$ tidak dapat memahami/menentukan keduanya. Hal ini berarti bahwa pesera didik lebih banyak tidak mampu memahami/menentukan kelima jenis indikator dibandingkan dengan mampu memahami /menentukan keduanya. Secara keseluruhan dari hasil tersebut, dapat diketahui bahwa profil kesulitan peserta didik berdasarkan pencapaian KKM untuk ke 5 jenis indikator masih sangat mengalami kesulitan yang termasuk dalam jenis kategori rendah. Hal ini menunjukkan bahwa rata-rata kesulitan peserta didik berdasarkan pencapaian KKM masih belum tuntas dengan masing-masing kategori lemah. Hal ini mungkin dikarenakan kurangnya penguasaan konsep dari peserta didik tentang gerak lurus

Apabila ditinjau pada aspek kesulitan peserta didik terhadap materi terlihat bahwa Dari lima sub materi pada materi gerak lurus ini, persentase profil kesulitan peserta didik pada sub materi jarak dan perpindahan sebesar 27,66\%, kecepatan dan kelajuan sebesar $7,66 \%$, percepatan sebesar $7 \%$, gerak lurus beraturan sebesar $23,83 \%$ dan gerak lurus berubah beraturan sebesar 9,55\%. Dari hasil tersebut pada sub materi jarak dan perpindahan memiliki persentase kesulitan lebih tinggi dari 
persentase sub materi yang lainnya sesuai yang tunjukkan pada Gambar 3. Kesulitan pada sub materi jarak dan perpindahan umumnya dikarenakan peserta didik merasa kesulitan dalam memprediksi jarak tempuh berdasarkan grafik yang ada. Hal ini dikarenakan peserta didik belum memahami konsep jarak dan perpindahan sesuai dengan hasil penelitian Pujianto dkk (2013) yaitu peserta didik memiliki pemahaman bahwa percepatan adalah kecepatan dibagi waktu. Konsepsi ini didasarkan pada rumus percepatan, tetapi belum memahami benda yang dipercepat maka jarak yang ditempuh setiap detiknya mengalami peningkatan. Persentase kesulitannya yaitu $27,66 \%$.

Secara keseluruhan dari hasil tersebut, dapat diketahui bahwa profil kesulitan peserta didik terhadap profil materi untuk semua jenis sub materi masih mengalami kesulitan yang termasuk dalam jenis kategori rendah. Hal ini menunjukkan bahwa rata-rata kesulitan peserta didik terhadap profil materi masih belum tuntas dengan masing-masing kategori lemah yang sesuai dengan ketentuan kategori kesulitan yang menyatakan persentase skor kurang dari $35 \%$ adalah kategori lemah. Upaya riil yang bisa dilakukan untuk mengatasai permasalahan ini adalah dengan cara memperbaiki proses pembelajaran. Salah satu pembelajaran yang bisa diterapkan adalah dengan menggunakan desain pembelajaran student's conceptual construction guider. Pembelajaran ini merupakan pembelajaran yang menggunakan pendekatan konstruktivisme. Dalam pembelajaran ini, peserta didik dipandu oleh guru dan lembar aktivitas peserta didik dengan pertanyaan-pertanyaan arahan untuk membimbing. Pertanyaan-pertanyaan ini dibuat dan dikembangkan berdasarkan urutan konten dan jenjang berpikir peserta didik. Selain itu, lembar aktivitas juga dibuat dalam upaya pengkonstruksian konsep dan aplikasi konsep. Sehingga peserta didik bisa mencapai hasil belajar yang optimal

\section{KESIMPULAN DAN SARAN}

Berdasarkan hasil investigasi dapat di simpulkan yaitu: (1). Kemampuan peserta didik dalam memecahkan masalah konsep gerak berbentuk grafik menunjukkan rata-rata kemampuan dengan kategori kurang yang dimulai dengan kemampuan interpretasi sebesar $10,14 \%$, interpolasi sebesar $30 \%$, ekstrakpolasi sebesar $16,66 \%$ dan kemampuan transformasi sebesar 19,11\%; (2). Profil kesulitan peserta didik berdasarkan pencapaian KKM masih mengalami kesulitan untuk semua indikator dengan rata-rata kategori lemah; (3) Profil kesulitan peserta didik terhadap materi masih mengalami kesulitan untuk semua sub materi dengan rata-rata kategori lemah

sebagai saran perbaikan untuk memaksimalkan hasil belajar diperlukan upaya peningkatan pemahaman peserta didik dalam berbagai bentuk interpretasi, memprediksi dan transformasi lain selain grafik, misalnya diagram, tabel ataupun verbal dan lainnya. Hal ini diperlukan agar pemahaman peserta didik menjadi lebih teruji tidak terbatas hanya pada satu bentuk. Sebaiknya juga dilakukan penelitian lanjutan untuk pemecahan masalah berbentuk grafik selain materi gerak lurus misalnya pada materi kinematika gerak melingkar. Selain itu, perlu adanya tindakan (treatment) remidiasi sebagai tindak lanjut dari tes diagnostik yang dilakukan dan perlu pembiasaan peserta didik dalam menghadapi permasalahan berbentuk grafik

\section{DAFTAR PUSTAKA}

Albab, U., Djudin, T., \& Oktavianty, E. (2020). Analisis Kemampuan Siswa Menyelesaikan Soal Berbentuk Grafik Pada Materi Usaha Gas Di Madrasah Aliyah. Jurnal Pendidikan dan Pembelajaran Khatulistiwa, 9(1).

Beichner, R,. J. (1994). Testing Student Interpretation of Kinematics Graphs. Nort Caroline State University : Releigh Caroline

Bunawan, W., Setiawan, A., \& Rusli, A. (2015). Penilaian pemahaman representasi grafik materi optika geometri menggunakan tes diagnostik. Jurnal Cakrawala Pendidikan, 34(2).

Erniwati, E., Sukariasih, L., Hunaidah, H., Sahara, L., Hasrida, H., Sirih, M., \& Fayanto, S. (2020). Analysis of Difficulty of Science Learning-Based Multi-Representation. Jurnal Pendidikan Fisika, 8(3), 263-278.

Hunaidah, M., Armin, A., \& Fayanto, S. (2018, May). Penerapan model pembelajaran PredictObserve-Explain (POE) dengan metode demonstrasi untuk meningkatkan aktivitas dan hasil belajar IPA Fisika materi pokok kalor Kelas VII2 SMP Negeri 15 Kendari. In Quantum: Seminar Nasional Fisika, dan Pendidikan Fisika (pp. 293-298).

Kawuri, M. Y. R. T., Ishafit, I., \& Fayanto, S. (2019). Efforts to improve the learning activity and learning outcomes of physics students with using a problem-based learning 
model. IJIS Edu: Indonesian Journal of Integrated Science Education, 1(2), 105-114.

Mustain, I. (2015). Kemampuan membaca dan interpretasi grafik dan data: Studi kasus pada siswa kelas 8 SMPN. Scientiae Educatia: Jurnal Pendidikan Sains, 4(2).

Nugroho, S.E., \& Darsono. 2007. Model Pembelajaran Dengan Peningkatan Guided Inquiry Untuk Meningkatkan Kemampuan Interpretasi Grafik Pada Mahasiswa Fisika. Laporan Penelitian. Semarang : FMIPA UNNES

Pujianto, A. (2013). Analisis konsepsi siswa pada konsep kinematika gerak lurus. JPFT (Jurnal Pendidikan Fisika Tadulako Online), 1(1), 1621.

Setiandari, D. (2013). Analisis Kesulitan Siswa dalam Mengerjakan Soal-soal Fisika Materi Gerak Lurus Kelas Vii Semester 2 SMP Tahun Ajaran 2011/2012. Universitas Sebelas Maret : Surakarta.

Setyono, A., Nugroho, S. E., \& Yulianti, I. (2016). Analisis Kesulitan Siswa dalam Memecahkan Masalah Fisika Berbentuk Grafik. UPEJ Unnes Physics Education Journal, 5(3), 3239.

Sugiyono. 2013. Metode Penelitian Pendekatan Kuantitatif, Kualitatif dan RnD. Alfabeta : Bandung

Yustiandi, Y., \& Saepuzaman, D. (2017). Profil Kemampuan Interpretasi Grafik Kinematika Siswa SMA Kelas X. Gravity: Jurnal Ilmiah Penelitian dan Pembelajaran Fisika, 3(1). 